\title{
A Systematic Review of the Effects of Exercise Interventions on Body Composition in $\mathrm{HIV}^{+}$Adults
}

\author{
L.L. Leach ${ }^{*}$, S.H. Bassett, G. Smithdorf, B.S. Andrews and A.L. Travill
}

Department of Sport, Recreation and Exercise Science, University of the Western Cape, Cape Town, South Africa

\begin{abstract}
Over the years, physical activity and exercise have been used to positively impact the health and quality of life of persons infected with HIV and, more recently, has been associated with a spectrum of body composition changes. The aim of this review was to examine the effects of various exercise interventions on body composition in HIV positive adults, using a search strategy of randomized, controlled trials (RCTs). A systematic review was performed by five independent reviewers using a predetermined protocol adapted from previous research for assessing the articles for inclusion, the extracted data, and methodological quality. Eight RCTs involving 430 (26\% female) HIV positive adults performing exercise a minimum of thrice weekly for at least six weeks were finally selected: Four were progressive resistance training (PRT) studies, three were aerobic training (AT) studies, and one involved yoga. In the PRT studies, there were significant increases in three anthropometric measures, namely, body mass, sum of skinfolds and sum of limb girths. In the AT studies, significant decreases were found in seven anthropometric measures, namely, body mass index, waist-hip ratio, body mass, triceps skinfold, waist circumference and sum of skinfolds. With yoga, the changes were nonsignificant. Exercise contributes to improved body composition and, when applied safely, appears to be beneficial for adults living with HIV/AIDS. However, these findings should be interpreted cautiously due to the relatively few RCTs published to date. Future studies would benefit from increased attention to sample size, female participants, participant follow-up, complete statistical analysis and intention-to-treat analysis.
\end{abstract}

Keywords: Acquired immune disease syndrome, anthropometry, body composition, exercise, human immunodeficiency virus, intervention, physical activity, randomised control trials.

\section{BACKGROUND AND RATIONALE}

Since the 1990s, the life expectancy of many adults living with HIV has increased significantly [1]. For many individuals living with HIV, the condition is gradually evolving into a chronic disease because of the increased longevity linked with progressive highly active antiretroviral therapy (HAART) [2]. However, HAART is associated with metabolic, morphologic and physiologic risk [3].

The lipodystrophy syndrome is an important secondary clinical complication associated with HAART that aggravates the treatment of HIV [4]. The defining features of this complex syndrome include fat loss (i.e., subcutaneous lipoatrophy), frequently observed in the face, arms, and legs, and/or the accretion of adipose tissue (lipohypertrophy) in the abdomen (protease pauch or Crixivan potbelly) and dorsocervical spine (the characteristic buffalo hump), and sporadic lipomas (subcutaneous fatty growths) [5]. Lipodystrophy severity remains a subjectively determined evaluation by physical examination and scores are calculated based on an evaluation of the face, neck/shoulders, arms, abdomen, and hips/legs with graded values from 0 to 3 for fat loss or accumulation [6]. A score $>2$ is used to indicate

*Address correspondence to this author at the Department of Sport, Recreation and Exercise Science, University of the Western Cape, Private Bag X17, Bellville 7535, South Africa; Tel: 27-21-9592653;

Fax: 27-21-9593688; E-mail: 1leach@uwc.ac.za lipodystrophy. Other risk factors for lipodystrophy include: age: older people are at higher risk; ethnicity: Whites have the highest risk; gender: men are more likely to have fat loss in the arms and legs, whereas women are more likely to have a buildup of breast and abdominal fat; and the length and severity of HIV infection: the risk is higher with longer and more severe HIV infection [7].

The distribution of body fat, especially when located centrally around the abdomen, is widely recognized as an important predictor of cardiovascular and metabolic risk [8]. Truncal obesity is a strong independent risk factor contributing to coronary heart disease [9]. Too much fat gain in the abdominal cavity provides an increased risk of hypertension [10], heart attacks [11, 12], type 2 diabetes [3] and premature mortality [13]. The stratification of cardiovascular risk associated with truncal (android) obesity is based upon a simple method of waist circumference measurement $>102 \mathrm{~cm}$ (men) or $>88 \mathrm{~cm}$ (women), or a waist-to-hip ratio (i.e., waist divided by hips circumference) $>0.95$ (men) or $>0.86$ (women) [14].

Currently, in the three classes of HAART medications, i.e., nucleoside reverse transcriptase inhibitors (NRTIs), nonnucleoside reverse transcriptase inhibitors (NNRTIs) and protease inhibitors (PIs), the use of protease inhibitors (PIs) has been strongly implicated in the problems associated with fat redistribution [4]. However, even the use of nucleoside reverse transcriptase inhibitors [15] and non-nucleoside reverse transcriptase inhibitors (NNRTIs) has shown similar 
complications [16]. The exact cause of lipodystrophy is unknown, but the use of HAART may be considered a major risk factor in fat redistribution and in the development of the lipodystrophy syndrome $[3,5]$.

The management of the lipodystrophy syndrome has been relatively challenging, if not difficult. Lipodystrophy can't be cured, but switching to newer HIV medicines are less likely to cause lipodystrophy than HIV medicines developed in the past [2]. Still, there remains a serious need to develop feasible interventions to manage the secondary side-effects of HAART medications. Deciding upon a simple, cost-effective nonpharmacological alternative makes sense as a logical starting point.

Over the years, physical activity and exercise training in particular have been used to positively impact the health and quality of life of persons infected with HIV and, more recently, in playing an increasingly protective role in alleviating lipodystrophy by favourably altering the body composition and patterns of body fat distribution [17- 20]. Exercise training has helped reduce the total body fat content and visceral fat in particular, as well as normalize the lipid profiles of HIV-infected individuals [21, 22]. A comprehensive multidisciplinary approach, inclusive of physical exercise, has proven to be one of the most efficacious and safe clinical therapies developed to date [23].

Progressive strength resistive training [24], aerobic endurance training [25] and concurrent strength and endurance training [26] for adults living with HIV/AIDS appears to be safe and, when applied appropriately, may lead to significant physiological improvements. These systematic reviews have shown that well-planned and specific exercise programmes are beneficial for individuals infected with HIV. However, each of these reviews have examined the exercise effects of strength training, endurance training, and concurrent training separately, unlike the present review where studies on the effects of strength training and studies on the effects of endurance training are examined in the same review. Previous reviews that examined the effects of aerobic and resistance training on body composition and fat distribution in $\mathrm{HIV}$-infected individuals lacked high quality studies based on randomised-controlled trials $[27,28]$. The number of good quality studies on the effects of exercise training targeting anthropometric and morphological outcomes is limited. Therefore, this review was undertaken to examine the available high quality scientific evidence on the effects of planned and structured PRT and AT on anthropometric and body composition outcomes as a means of addressing the risk associated with the fat redistribution in HIVinfected individuals on HAART medication. The value of such a review may contribute to positive health outcomes by enabling a better understanding of the effectiveness of various types of exercise training on body composition and anthropometry for the benefit not only of persons living with HIV, but also for healthcare practitioners involved in managing HIV patients.

\section{METHODS}

\section{Data Sources and Searches}

During May 2013, a comprehensive search was conducted in selected databases (January 1980 to May 2013) for original research articles published in English. The searched databases were PubMed, Sport Discus, Science Direct, Biomed Central, and Academic Search Complete. Manual tracking of citations in selected articles was then completed. The search terms used in various combinations were: HIV; adults; exercise; sport; physical activity; anthropometric; anthropometry; body mass; body composition; body fat; and fat distribution.

The titles and abstracts of the identified literature were screened by five independent reviewers using the inclusion criteria listed below. Next, the full text of all potentially relevant articles was retrieved and screened by the reviewers to determine final eligibility of studies for the review.

\section{Inclusion Criteria}

The criteria for inclusion of studies into the systematic review were:

- Articles published in English

- $\quad$ Randomised controlled trials (RCTs)

- HIV positive adults $\geq 18$ years with or without lipodystrophy

- Any physical activity, exercise, aerobic training, resistance training, and/or sport participation performed a minimum of twice weekly for at least 4 weeks, with or without supervision

- $\quad$ Outcome measures that included body composition (fat mass, lean body mass, muscle cross-sectional area, etc.) and/or anthropometric measurements (e.g., stature, body mass, skinfolds)

Studies not meeting these criteria were excluded from this review.

\section{Methods of the Review}

Initially, each database search was conducted by one reviewer, and the selected abstracts and titles were verified by another. Potentially relevant studies that met the inclusion criteria were retrieved and totalled 185 studies. Next, all duplicate studies were removed that reduced the number of studies to 25 . Thereafter, an additional 10 articles were identified from manual searches of previous reviews, conference abstracts and bibliographic references. However, only four of these studies met the inclusion criteria of the systematic review and were added. The full texts of the 29 studies were retrieved and independently read by each reviewer to determine its eligibility in the systematic review. From the 29 studies, 21 were excluded based on not being randomised-controlled trials $(\mathrm{n}=12)$, using concurrent exercise training protocols $(n=6)$, not reporting the $p$ values $(\mathrm{n}=2)$ and having repeated data $(\mathrm{n}=1)$. A flowchart of the process is presented in Fig. (1). Inclusion in the systematic review was based on the methodological quality of the study as described below.

\section{Methodological Quality Appraisal}

The methodological quality of each of the 8 papers was assessed independently by each of the authors using the 
Table 1. Critical appraisal tool for evaluating eligibility of the selected studies.

\begin{tabular}{|c|c|c|c|}
\hline \multirow{3}{*}{1} & \multicolumn{2}{|c|}{ Did the study ask a clearly-focused question/Purpose? } & Score \\
\hline & A. & Yes & 1 \\
\hline & B. & No & 0 \\
\hline \multirow{3}{*}{2} & \multicolumn{3}{|c|}{ Was the sampling method representative of the population intended for the study? } \\
\hline & A. & Yes & 1 \\
\hline & B. & No & 0 \\
\hline \multirow[t]{2}{*}{3} & A. & Yes & 1 \\
\hline & B. & No & 0 \\
\hline \multirow[b]{2}{*}{4} & \multicolumn{3}{|c|}{ Was this a randomised controlled trial (RCT)? } \\
\hline & A. & Yes & 1 \\
\hline \multirow[t]{2}{*}{5} & A. & Yes & 1 \\
\hline & B. & No & 0 \\
\hline \multirow{3}{*}{6} & \multicolumn{3}{|c|}{ Were participants, staff and study personnel 'blind' to participants' study group? } \\
\hline & A. & Yes & 1 \\
\hline & B. & No & 0 \\
\hline \multirow{3}{*}{7} & \multicolumn{3}{|c|}{ Were the groups similar at baseline? } \\
\hline & A. & Yes & 1 \\
\hline & B. & No & 0 \\
\hline \multirow{3}{*}{10} & \multicolumn{3}{|c|}{ Were the actual p-values reported? } \\
\hline & A. & Yes & 1 \\
\hline & B. & No & 0 \\
\hline
\end{tabular}

Scoring method: Total score divided by total number of all applicable items multiplied by 100

Grading of the quality assessment checklist for observation $(Q A C O)$ score:

$\begin{array}{ccc}\text { Low } & \text { Moderate } & \text { High } \\ 0-33 \% & 34-66 \% & 67-100 \%\end{array}$

CASP (Critical Appraisal Skills Programme) tool (Table 1). This tool was adapted from previous research [29, 30]. Studies were independently rated by the reviewers for 10 items, and used to calculate the method score as a percentage that was assigned a low $(\leq 33 \%)$, moderate $(34-66 \%)$ or high $(\geq 67 \%)$ rating. The authors decided previously that studies falling below the cut-off score of $67 \%$ would be excluded from the review. Differences in scoring between the authors were resolved by open discussion between all the authors together. Upon completion of the appraisal, it was agreed to retain all 8 articles in the review. The results of the appraisal process are shown in Table 2.

\section{Data Extraction}

A data extraction sheet was designed by two reviewers to identify relevant information, such as the authors, date of publication, aim or purpose of the study, study design, population (sample size, age, HIV status, and country), and anthropometric methods used (Table 3 ).

\section{Data Analysis}

The selection of studies for the systematic review was based on quality appraisal and were grouped according to similarities in exercise intervention and subsequently analysed. The results are reported descriptively, 


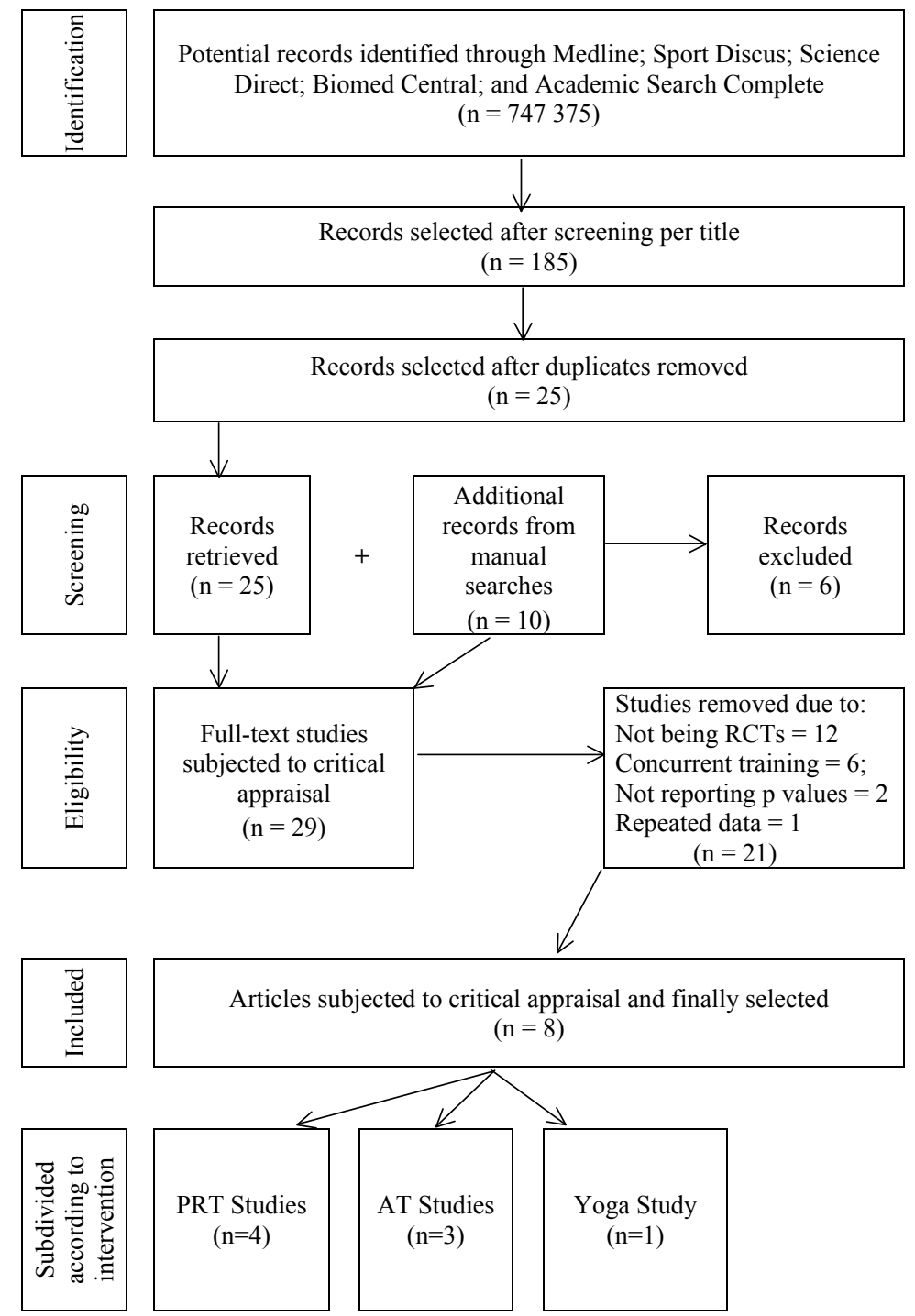

Fig. (1). Flowchart of screening of articles is based on the 2009 PRISMA flow diagram.

Table 2. Method of scoring of articles based on the critical appraisal tool.

\begin{tabular}{|c|c|c|c|c|c|c|c|c|c|c|c|}
\hline Author & 1 & 2 & 3 & 4 & 5 & 6 & 7 & 8 & 9 & 10 & Score \\
\hline Spence et al. (1990) & 1 & 1 & 1 & 1 & 1 & 0 & 1 & 1 & 1 & 1 & $67-100 \%$ \\
\hline Bhasin et al. (2000) & 1 & 1 & 1 & 1 & 1 & 1 & 1 & 1 & 1 & 1 & $67-100 \%$ \\
\hline Smith et al. (2001) & 1 & 1 & 1 & 1 & 1 & 0 & 1 & 1 & 1 & 1 & $67-100 \%$ \\
\hline Terry et al. (2006) & 1 & 1 & 1 & 1 & 1 & 0 & 1 & 1 & 1 & 1 & $67-100 \%$ \\
\hline Mutimura et al. (2008) & 1 & 1 & 1 & 1 & 1 & 0 & 1 & 1 & 1 & 1 & $67-100 \%$ \\
\hline Cade et al. (2010) & 1 & 1 & 1 & 1 & 1 & 0 & 1 & 1 & 1 & 1 & $67-100 \%$ \\
\hline
\end{tabular}

accompanied by tables that included three characteristics: population studied, intervention ( $\mathrm{s}$ ) applied and outcomes measured. The change in anthropometric and body composition outcome measures from pre- to post-treatment are represented as percentages and the $p$-values between control and experimental groups indicated, if reported. Due to the small number of studies reviewed, the clinical heterogeneity between studies regarding population, intervention and outcome measures, and the small sample sizes, the decision to pursue further meta-analysis was contra-indicated. Therefore, the data analysis and results of the studies are based on the strength of the evidence of individual studies. 
Table 3. Key features of studies included in the systematic review.

\begin{tabular}{|c|c|c|c|c|}
\hline Reference & Aim/Purpose & Design & Population & Methods: Anthropometry \\
\hline \multicolumn{5}{|c|}{ Progressive Resistance Training (PRT) Intervention Studies (n=4) } \\
\hline Sattler et al. (1999) & $\begin{array}{l}\text { To determine whether } \\
\text { anabolic steroids with and } \\
\text { without PRT increases in } \\
\text { lean tissue, muscle size and } \\
\text { strength in HIV-infected, } \\
\text { immune deficient men. }\end{array}$ & $\begin{array}{l}\text { RCT } \\
\text { PRT with } \\
\text { nandrolone } \\
\text { decanoate } \\
\text { injections } 600 \\
\text { mg/week. }\end{array}$ & $\begin{array}{l}\text { HIV-seropositive men }(\geq 18 \mathrm{y}) \text {. } \\
33 \text { started; } 30 \text { completed. } \\
\text { Dropout }=3(9.1 \%) .2 \text { groups: nandrolone only } \\
(\mathrm{n}=17 / 15 ; \mathrm{d} / \mathrm{o}=11.8 \%) \text { and nandrolone plus } \\
\text { PRT }(\mathrm{n}=16 / 15 ; \mathrm{d} / \mathrm{o}=6.3 \%) \text {. Los Angeles, USA }\end{array}$ & $\begin{array}{l}\text { Measures taken at baseline and } \\
12 \text { weeks. Instruments: DEXA, } \\
\text { MRI and BIA Outcome } \\
\text { Measures: BM, LBM, FM, } \\
\text { body cell mass, arm and thigh } \\
\text { MCSA. }\end{array}$ \\
\hline Shevitz et al. (2005) & $\begin{array}{l}\text { To determine the effect of } \\
\text { nutrition with-strength } \\
\text { training on AIDS wasting. }\end{array}$ & $\begin{array}{l}\text { RCT PRT with } \\
\text { nutrition } \\
\text { intervention. }\end{array}$ & $\begin{array}{l}\text { Men and women }(\geq 18 \mathrm{y}) \text { with AIDS wasting } \\
\text { syndrome. } \\
50 \text { started; } 47 \text { completed. } \\
\text { Dropout }=3(6.0 \%) .3 \text { groups: Nutrition only } \\
(\mathrm{n}=18 / 16 ; \mathrm{d} / 0=11.1 \%) ; \text { nutrition plus } \\
\text { oxandrolone }(\mathrm{n}=16 / 16 ; \mathrm{d} / \mathrm{o}=0 \%) ; \text { and nutrition } \\
\text { plus PRT }(\mathrm{n}=16 / 15 ; \mathrm{d} / \mathrm{o}=6.3 \%) \text {. Boston, } \\
\text { Massachusetts. }\end{array}$ & $\begin{array}{l}\text { Measures taken at baseline and } \\
12 \text { weeks. Instruments: Digital } \\
\text { scale, DEXA and CT scanner. } \\
\text { Outcome Measures: Stature, } \\
\text { BM, BMI, thigh MCSA, FM, } \\
\text { and FFM. }\end{array}$ \\
\hline \multicolumn{5}{|c|}{ Aerobic Training (AT) Intervention Studies $(n=3)$} \\
\hline Terry et al. (2006) & $\begin{array}{l}\text { To determine the effect of } \\
\text { AT and a low-lipid diet on } \\
\text { dyslipidaemia and } \\
\text { lipodystrophy in HIV-1- } \\
\text { infected adults. }\end{array}$ & $\begin{array}{l}\text { RCT } \\
\text { AT with diet. }\end{array}$ & $\begin{array}{l}\text { HIV-1-infected men and women }(\geq 18 \mathrm{y}) \text {. } \\
42 \text { started; } 30 \text { completed. } \\
\text { Dropout }=12(28.6 \%) .2 \text { groups: Diet and AT } \\
(\mathrm{n}=22 / 15 ; \mathrm{d} / \mathrm{o}=31.9 \%) \text { and diet only }(\mathrm{n}=20 / 15 \\
\mathrm{d} / \mathrm{o}=25.0 \%) . \text { Porto Alegre, Brazil. }\end{array}$ & $\begin{array}{l}\text { Measures taken at baseline and } \\
12 \text { weeks. Instruments: } \\
\text { Anthropometric tape and } \\
\text { skinfold calliper. Outcome } \\
\text { Measures: Stature, BM, BMI, } \\
\text { waist and hip circumference, } \\
\text { WHR, FM, and } 4 \text { SF (triceps, } \\
\text { biceps, subscapular, suprailiac) }\end{array}$ \\
\hline $\begin{array}{l}\text { Mutimura et al. } \\
\text { (2008) }\end{array}$ & $\begin{array}{l}\text { To determine the effect of } \\
\text { AT on central obesity and } \\
\text { metabolic indices in } \\
\text { HAART-treated HIV- } \\
\text { positive adults. }\end{array}$ & $\begin{array}{l}\text { RCT } \\
\text { AT intervention } \\
\text { only. }\end{array}$ & $\begin{array}{l}\text { HIV-positive men and women }(21-50 \mathrm{y}) \text { on } \\
\text { HAART for }>6 \text { months. } \\
100 \text { started; } 97 \text { completed. } \\
\text { Dropout }=3(3.0 \%) .2 \text { groups: } \mathrm{ET}(\mathrm{n}=50 / 48 ; \\
\mathrm{d} / \mathrm{o}=4.0 \%) \text { and control }(\mathrm{n}=50 / 49 ; \mathrm{d} / \mathrm{o}=2.0 \%) \text {. } \\
\text { Kigali, Rwanda }\end{array}$ & $\begin{array}{l}\text { Measures taken at baseline and } \\
24 \text { weeks. Instruments: Cloth } \\
\text { tape measure and skinfold } \\
\text { calliper. Outcome Measures: } \\
\text { Stature, BM, FM, LBM, waist } \\
\text { and hip circumference, WHR, } \\
\text { 4SF (triceps, biceps, suprailiac, } \\
\text { subscapular). }\end{array}$ \\
\hline \multicolumn{5}{|c|}{ Yoga Intervention Study $(\mathrm{n}=1)$} \\
\hline Cade et al. (2010) & $\begin{array}{l}\text { To determine the effect of } \\
\text { yoga on CVD risk factors, } \\
\text { body composition, immune } \\
\text { and virological status and } \\
\text { health-related QOL in HIV- } \\
\text { infected adults. }\end{array}$ & $\begin{array}{l}\text { RCT } \\
\text { Yoga with nutrition } \\
\text { counselling }\end{array}$ & $\begin{array}{l}\text { HIV-infected men and women }(18-70 \mathrm{y}) \\
60 \text { started; } 50 \text { completed. } \\
\text { Dropout }=10(16.7 \%) .2 \text { groups: Yoga }(\mathrm{n}=34 / 29 ; \\
\mathrm{d} / \mathrm{o}=14.7 \%) \text { and control }(\mathrm{n}=26 / 21 ; \mathrm{d} / \mathrm{o}=19.2 \%) \\
\text { Missouri, USA }\end{array}$ & $\begin{array}{l}\text { Measures taken at baseline and } \\
20 \text { weeks. Instruments: } \\
\text { Anthropometric tape and } \\
\text { DEXA. Outcome Measures: } \\
\text { BM, waist circumference, FM, } \\
\text { limb fat, trunk fat, LBM, and } \\
\text { limb lean mass. }\end{array}$ \\
\hline
\end{tabular}




\section{RESULTS}

The eight articles finally selected for this review were located predominantly in the USA (Massachusetts = 1 study; Missouri $=1$ study; Texas $=2$ studies; and California $=2$ studies), with one in Porto Alegre, Brazil and one in Kigali, Rwanda. These articles were further subdivided into the method of intervention utilised, i.e., whether progressive resistance training (PRT) (four articles), aerobic training (AT) (three articles) and yoga (one article). These details are presented in Table $\mathbf{3}$.

\section{Characteristics of the Sample}

In the eight studies selected for the systematic review, the participants' ages ranged from 18 to 70 years. At the onset of treatment, the sample sizes across the eight studies ranged from 24 participants [31] to 100 participants [21]. The total number of participants in the eight studies was 430, with 112 $(26 \%)$ female. However, 54 participants (12.6\%) dropped out across the eight studies, so that the final study samples ranged from 24 participants [12] to 97 participants [21], and involved a total of 376 participants. Participants were ethnically diverse, weight stable, sedentary adults of both genders, but the majority $(74 \%)$ were male. All participants were outpatients diagnosed with HIV at various stages of the disease with CD4 counts ranging from less than 200 to above 1000 cells $\cdot \mathrm{mm}^{-3}$, and all were on a stable combination antiretroviral therapy regimen. In some of the studies the participants also had signs of body fat redistribution and evidence of dyslipidemia and lipodystrophy, and some with AIDS wasting syndrome, but post-pneumocystis carinii pneumonia and opportunistic infections with stable body mass. All participants were also injury-free and without any exercise contra-indications.

\section{Outcomes of Included Studies}

The most commonly measured variables in the eight studies were stature, body mass (BM), body mass index (BMI), lean body mass (LBM) and fat mass (FM). Common assessment techniques used in the various studies were dual energy X-ray absorptiometry (DEXA) scanning (four studies), and standardised manual techniques involving skinfold callipers and anthropometric tape measures (four studies). More sophisticated techniques to determine body composition and muscle cross-sectional area included magnetic resonance imaging (MRI) (2 studies) computerised tomography (CT) scan (one study), deuterium oxide dilution method (DDM)(one study) and bioelectrical impedance analysis (BIA) (one study). Other body composition variables measured were total body water (TBW), visceral adipose tissue (VAT) and muscle attenuation.

\section{Characteristics of the Intervention Programmes.}

The characteristics of the exercise interventions in the various studies are provided in Table 4 . The duration or

Table 4. Characteristics of the exercise protocols of the studies included in the systematic review.

\begin{tabular}{|c|c|c|c|c|c|c|c|}
\hline Study & $\begin{array}{c}\text { Type of } \\
\text { Intervention }\end{array}$ & $\begin{array}{c}\text { Intensity/Progression } \\
\text { (Weeks) }\end{array}$ & Volume & $\begin{array}{c}\text { Frequency (Sessions } \\
\text { Per Week) }\end{array}$ & $\begin{array}{c}\text { Time } \\
\text { (Minutes) }\end{array}$ & $\begin{array}{l}\text { Length } \\
\text { (Weeks) }\end{array}$ & Supervision \\
\hline $\begin{array}{l}\text { Spence et al. } \\
\quad(1990)\end{array}$ & PRT & $100 \% 1 \mathrm{RM}$ & $\begin{array}{l}1 \text { set } 15 \text { reps (unit } 1 \text { ) } 3 \text { sets } 10 \text { reps (unit } \\
6 \text { ) }\end{array}$ & 3 & NR & 6 & Yes \\
\hline $\begin{array}{l}\text { Sattler et al. } \\
\quad(1999)\end{array}$ & PRT & $\begin{array}{l}70 \% 1 \mathrm{RM}(2 \text { weeks }) \\
80 \% 1 \mathrm{RM}(10 \text { weeks })\end{array}$ & 1 set $5-8$ reps warm up 3 sets 8 reps & 3 & NR & 12 & Yes \\
\hline $\begin{array}{l}\text { Bhasin et al. } \\
\quad(2000)\end{array}$ & PRT & $\begin{array}{l}60 \% 1 \mathrm{RM} \text { (4 weeks) } 70- \\
90 \% 1 \mathrm{RM}(6 \text { weeks) } 7 \% \\
\text { UB \& } 12 \% \text { LB (6 weeks) }\end{array}$ & $\begin{array}{l}3 \text { sets } 12-15 \text { reps } 4 \text { sets } 4-6 \text { reps } 5 \text { sets } \\
4-6 \text { reps }\end{array}$ & 3 & NR & 16 & NR \\
\hline $\begin{array}{l}\text { Shevitz et al. } \\
\quad(2005)\end{array}$ & PRT & $\begin{array}{l}\text { Goal intensity of } 80 \% 1 \\
\text { RM }\end{array}$ & 3 sets 8 reps & 3 & $30-60$ & 12 & Yes \\
\hline $\begin{array}{l}\text { Smith et al. } \\
\quad(2001)\end{array}$ & AT & $60-80 \% \mathrm{VO}_{2 \max }$ & 30 min exercise & 3 & 30 & 12 & Yes \\
\hline $\begin{array}{l}\text { Terry et al. } \\
\quad(2006)\end{array}$ & AT & $70-85 \% \mathrm{HR}_{\max }$ & $\begin{array}{l}\text { 15-min warm-up } 30 \text { min exercise } 15 \\
\text { min cool down }\end{array}$ & 3 & 60 & 12 & Yes \\
\hline $\begin{array}{l}\text { Mutimura et } \\
\text { al. (2008) }\end{array}$ & AT & $\begin{array}{l}45 \% \mathrm{HR}_{\max }(3 \text { weeks }) \\
60 \% \mathrm{HR}_{\max }(6 \text { weeks }) \\
75 \% \mathrm{HR}_{\max }(15 \text { weeks })\end{array}$ & $\begin{array}{l}\text { 15-min warm-up 45-60 min exercise } 15 \\
\text { min cool down }\end{array}$ & 3 & 90 & 24 & Yes \\
\hline $\begin{array}{l}\text { Cade } \text { et al. } \\
\quad \text { (2010) }\end{array}$ & Yoga & $\begin{array}{l}\text { The maximum rate of } \\
\text { respirations would last } \\
35-45 \text { s per static pose } \\
\text { (asana) }\end{array}$ & $\begin{array}{l}\text { 1. Alignment of muscle locks (bandhas) } \\
\text { and controlled } \\
\text { breathing (ujjayi). } \\
\text { 2. Warm-up ( } 5 \mathrm{~min}) \text {. } \\
\text { 3. Sun salute A x3, salute B x1 (surya } \\
\text { namaskara) ( } 7 \mathrm{~min}) \text {. } \\
\text { 4. Standing asanas ( } 25 \mathrm{~min}) \text {. } \\
\text { 5. Seated asanas ( } 10 \mathrm{~min}) \text {. } \\
\text { 6. Lying supine asanas (5 min). } 7 \text {. } \\
\text { Cool-down ( } 7 \text { min). }\end{array}$ & $2-3$ & 60 & 20 & Yes \\
\hline
\end{tabular}

$\mathrm{AT}=$ aerobic training; $\mathrm{HR}_{\max }=$ maximum heart rate; $\mathrm{HRR}=$ heart rate reserve; $\mathrm{LB}=$ lower body; $\mathrm{NR}=$ not reported; $\mathrm{PRT}=$ progressive resistance training; $\mathrm{RM}=$ repetition maximum; Reps = repetitions; $\mathrm{UB}=$ upper body; $\mathrm{VO}_{2 \max }=$ percent maximum volume of oxygen consumption . 
length of time of the intervention programmes ranged from 6 to 24 weeks, with the most common intervention period being 12 weeks (four studies).

\section{Type}

In the eight articles selected, the types of exercise interventions were categorised into three (3) groups, viz., progressive resistance training (PRT) (4 studies), aerobic training (AT) (3 studies), and yoga (1 study). The parameters used in the application of resistance or aerobic training were reported in most studies, and some described the progressive nature of the training. However, the intensity of exercise was not described in one study, the duration of the exercise sessions was not described in three, and supervision was not reported in one of the studies.

For the application of aerobic training, the studies reported using a track, treadmill, stationary cycle, stair stepper or cross-country machine. For resistance training, Spence et al. [31] used isokinetic equipment (Total Power hydraulic resistance unit). Sattler et al. [19] used free weights and Shevitz et al. [32] the Keiser pneumatic strength training machines, whereas the study by Bhasin et al. [33] had no description of the type of equipment used. In the yoga study of Cade et al. [34], the application used was body alignment through muscle locks (bandhas) and controlled breathing (ujjayi) in the warm-up, then sun salute A x 3, salute B x 1 (surya namaskara), standing asanas, seated asanas, lying supine asanas, and finally the cool-down (restorative breathing techniques). The intensity was based on the respiratory rate (ujjayi) used to adjust the timing and transitions of the sequences.

\section{Frequency}

The frequency of sessions was mostly three times a week, except for the yoga sessions which varied between 2 to 3 sessions per week.

\section{Intensity}

Except for the study by Spence et al. [31] where the exercise intensity was not reported, the exercise intensity for the other PRT studies was based on the weight lifted in one repetition maximum (1 RM, defined as the maximal load that could be lifted throughout the joint range of motion once), ranging from $50-90 \% 1 \mathrm{RM}$ for various muscle groups. The application of training volume ranged from 1 to 5 sets, with the number of repetitions ranging from the point of failure to complete up to 15 repetitions per set.

In the three (3) AT studies, the exercise intensity was based on either maximal heart rate $\left(\mathrm{HR}_{\max }\right)$, ranging from 45 $85 \%$ or maximal oxygen consumption $\left(\mathrm{VO}_{2 \max }\right)$, ranging from $60-80 \%$.

In the one (1) yoga study, exercise intensity was based on respiratory breathing rate with novice participants accommodated by allowing more time between body position transitions and coupling breathing to movement.

\section{Time}

In terms of the length of each training session, in the PRT studies, most did not mention a session duration, but training was performed 3 times per week for 6 weeks (one study), 12 weeks ( 2 studies), and 16 weeks ( 1 study). In the AT studies, the session duration ranged from 30 to 90 minutes, with training performed 3 times per week for 12 weeks (2 studies), and 24 weeks (1 study). In the yoga study, the session duration was 60 minutes, performed for 20 weeks.

\section{Progression}

In the four PRT studies, at least three of the studies used a baseline of 1 repetition maximum (1 RM) to acclimate the subjects to the training programme, except for Spence et al. [31] where no exercise intensity was stated. Although progression was applied for most of the PRT studies, unfortunately there was not consistent standardised protocol used across the studies.

For Spence et al. [31], the resistance load was uniformly increased throughout the six week training programme from 1 set of 15 repetitions (minimum loading on unit 1) to 3 sets of 10 repetitions (maximum loading on unit 6). Bhasin et al. [33] used a progressive, periodized strength training programme over 16 weeks, starting with high volume, low resistance training at $60 \% 1 \mathrm{RM}$ for the first 4 weeks that progressed to a high-intensity resistance programme $(90 \% 1$ RM on heavy days, $80 \% 1 \mathrm{RM}$ on medium days, and $70 \% 1$ RM on light days) for the next 6 weeks (weeks 5 to 10). For the last 6 weeks (weeks 11 through 16), the resistance was increased by $7 \%$ for upper body and $12 \%$ for lower body exercises. In the yoga study, as participants progressively improved in the yoga programme, respiratory rate (ujjayi) was used to adjust the timing and transitions of the exercise sequences [34].

\section{Adherence to Exercise Programme}

Adherence to exercise is the ability to remain participating in an exercise programme for a predetermined period of time. In this review, from the 430 (26\% female) participants who entered the protocols, 376 (87.4\%) remained in the studies at closure, with 54 (12.6\%) dropping out. For the PRT studies specifically, of the $168(8.9 \%$ female) participants who started out, 18 (10.7\%) dropped out leaving a total of 150 participants. For the AT studies specifically, of the 202 (41.6\% female) participants who started out, $26(12.9 \%)$ dropped out leaving a total of 176 participants. For the yoga study, of the 60 (21.7\% female) participants who started out, $10(16.7 \%)$ dropped out leaving a total of 50 participants. Because drop out was not specified by gender in some of the studies, it was difficult to decide whether this was a contributing factor to dropout rate.

Table 5 shows that the number of variables measured and the instruments used varied across the 4 PRT studies reviewed. Statistically significant differences were reported in two studies, whereas the remaining results were either not significant or not reported in the studies. 
Table 5. Analysis of results from the four progressive resistance training (PRT) studies.

\begin{tabular}{|c|c|c|c|c|c|c|c|c|c|c|c|c|}
\hline \multirow{2}{*}{ Authors } & \multirow{2}{*}{ Variables } & \multicolumn{4}{|c|}{ Control Group } & \multicolumn{4}{|c|}{ Experimental Group } & \multicolumn{2}{|c|}{ Between Groups } & \multirow{2}{*}{$p$-Value } \\
\hline & & Pre $^{+}$ & Post $^{+}$ & Diff. & $\%$ Change & Pre $^{+}$ & Post $^{+}$ & Diff. & $\%$ Change & Diff. & \% Change & \\
\hline \multirow{3}{*}{$\begin{array}{l}\text { Spence } \\
\text { et al. } \\
(1990)\end{array}$} & Body Mass (kg) & 69.3 & 67.4 & -1.9 & -2.7 & 70.8 & 72.5 & 1.7 & 2.4 & 3.6 & 5.1 & 0.000 \\
\hline & Sum of Skinfolds (mm) & 61.9 & 57.0 & -4.9 & -7.9 & 65.4 & 70.5 & 5.1 & 7.8 & 10.0 & 15.7 & 0.009 \\
\hline & Sum of Limb Girths (cm) & 78.5 & 76.3 & -2.2 & -2.8 & 80.2 & 83.7 & 3.5 & 4.4 & 5.7 & 7.2 & 0.003 \\
\hline \multirow{7}{*}{$\begin{array}{l}\text { Sattler } \\
\text { et al. } \\
(1999)\end{array}$} & Body Mass (kg) & 73.3 & 76.5 & 3.2 & 4.4 & 70.9 & 74.9 & 4.0 & 5.6 & 0.8 & 1.3 & NS \\
\hline & Fat Mass (kg) & 13.6 & 13.1 & -0.5 & -3.7 & 13.2 & 12 & -1.2 & -9.1 & -0.7 & -5.4 & NS \\
\hline & Fat Free Mass (kg) & 57.1 & 61 & 3.9 & 6.8 & 55.3 & 60.5 & 5.2 & 9.4 & 1.3 & 2.6 & NS \\
\hline & Body cell mass (kg) & 29.5 & 32.1 & 2.6 & 8.8 & 28.7 & 31.6 & 2.9 & 10.1 & 0.3 & 1.3 & NS \\
\hline & Thigh Muscle Cross-Sectional Area $\left(\mathrm{mm}^{2}\right)$ & 12933 & 14471 & 1538.0 & 11.9 & 12172 & 13652 & 1480.0 & 12.2 & -58.0 & 0.3 & NS \\
\hline & Quadriceps Muscle Cross-Sectional Area $\left(\mathrm{mm}^{2}\right)$ & 6683 & 7388 & 705.0 & 10.5 & 6322 & 7049 & 727.0 & 11.5 & 22.0 & 1.0 & NS \\
\hline & Hamstrings Muscle Cross-Sectional Area $\left(\mathrm{mm}^{2}\right)$ & 6200 & 7042 & 842.0 & 13.6 & 5818 & 6588 & 770.0 & 13.2 & -72.0 & -0.3 & NS \\
\hline \multirow{12}{*}{$\begin{array}{l}\text { Bhasin } \\
\text { et al. } \\
(2000)\end{array}$} & Body Mass $(\mathrm{kg})^{\#}$ & 76.7 & 76.1 & -0.6 & -0.8 & 73 & 75.6 & 2.6 & 3.6 & 3.2 & 4.3 & $<.05$ \\
\hline & Fat Mass $(\mathrm{kg})^{\#}$ & 16.6 & 16.5 & -0.1 & -0.6 & 15.1 & 15.7 & 0.6 & 4.0 & 0.7 & 4.6 & NR \\
\hline & Free Free Mass $(\mathrm{kg})^{\#}$ & 60.1 & 59.6 & -0.5 & -0.8 & 57.9 & 59.9 & 2.0 & 3.5 & 2.5 & 4.3 & NR \\
\hline & $\mathrm{TBW}(\mathrm{kg})^{\#}$ & 43.8 & 43.5 & -0.3 & -0.7 & 42.3 & 43.7 & 1.4 & 3.3 & 1.7 & 4.0 & NR \\
\hline & TBW:FFM (ratio) & 0.78 & 0.77 & 0.0 & -1.3 & 0.77 & 0.75 & 0.0 & -2.6 & 0.0 & -1.3 & NR \\
\hline & Thigh muscle volume $\left(\mathrm{cm}^{3}\right)$ (MRI) & NR & NR & 5 & $\mathrm{NC}$ & NR & NR & 62 & $\mathrm{NC}$ & 57 & $\mathrm{NC}$ & $<.01$ \\
\hline & Body Mass $(\mathrm{kg})^{t}$ & 74.3 & 72.1 & -2.2 & -3.0 & 63.9 & 74 & 10.1 & 15.8 & 12.3 & 18.8 & NR \\
\hline & Fat Mass $(\mathrm{kg})^{t}$ & 17.7 & 15.6 & -2.1 & -11.9 & 13.4 & 15.6 & 2.2 & 16.4 & 4.3 & 28.3 & NR \\
\hline & Fat Free Mass $(\mathrm{kg})^{+}$ & 56.6 & 56.5 & -0.1 & -0.2 & 50.5 & 58.4 & 7.9 & 15.6 & 8.0 & 15.8 & NR \\
\hline & Lean Body Mass arms $(\mathrm{kg})^{+}$ & 6.7 & 6.9 & 0.2 & 3.0 & 6.5 & 7.0 & 0.5 & 7.7 & 0.3 & 4.7 & NR \\
\hline & Lean Body Mass legs $(\mathrm{kg})^{*}$ & 17.3 & 17.5 & 0.2 & 1.2 & 17.1 & 17.8 & 0.7 & 4.1 & 0.5 & 2.9 & NR \\
\hline & Lean Body Mass trunk $(\mathrm{kg})^{t}$ & 26.3 & 26.0 & -0.3 & -1.1 & 25.9 & 27.2 & 1.3 & 5.0 & 1.6 & 6.2 & NR \\
\hline \multirow{3}{*}{$\begin{array}{l}\text { Shevitz } \\
\text { et al. } \\
(2005)\end{array}$} & Body Mass Index $\left(\mathrm{kgm}^{-2}\right)$ & 20.8 & 21.2 & 0.4 & 1.9 & 20.6 & 20.99 & 0.4 & 1.9 & 0.0 & 0.0 & NS \\
\hline & Fat Free Mass (kg) & 53.3 & 54.2 & 0.9 & 1.7 & 45.2 & 46.37 & 1.2 & 2.6 & 0.3 & 0.9 & NS \\
\hline & Leg Muscle Cross-Sectional Area $\left(\mathrm{cm}^{2}\right)$ & 122.3 & 124.3 & 2.0 & 1.6 & 113.1 & 118.4 & 5.3 & 4.7 & 3.3 & 3.1 & NS \\
\hline
\end{tabular}

Diff. = difference; $\mathrm{MCSA}=$ muscle cross-sectional area; $\mathrm{NC}=$ not calculated; $\mathrm{NR}=$ not reported; $\mathrm{NS}=$ not significant.

${ }^{+}$Values indicated as means

"Indicates measurements taken using deuterium oxide dilution method (DDM).

${ }^{\ddagger}$ Indicates measurements taken using dual energy X-ray absorptiometry (DEXA).

Table 6 shows the list of variables measured across the four PRT studies, expressed as a percentage. The study by Bhasin et al. [33] Used two differing techniques for measuring body composition (DDM and DEXA scanning), and was considered as two studies for reporting purposes. The table, therefore, reports the number of studies as five, and also indicates whether the change in the variables measured were significant or not. In addition, the direction of the change (trend) was also indicated as being an increase, decrease or no change. The percentage change for each study was also added to determine the overall percentage change or general strength of change. The variables measured in more than one study were grouped and presented first, and the variables measured in only one study were grouped and presented next. Body mass was measured in four of the five studies, with two of the studies showing significant change. All four studies indicated an increase in BM with PRT, and the strength as $29.5 \%$. Fat free mass was measured in four of the five studies, with none of the studies showing significant change. All the studies, nevertheless, indicated an increase in FFM with PRT and the overall strength of change as $23.6 \%$. Fat mass was measured in three of the five studies, with none of the studies showing significant change. Two studies indicated a decrease, whereas the other study indicated an increase, and the overall strength as an increase of $27.5 \%$. Leg MCSA was also measured in two studies, with none of the studies showing significant change. Both studies, nevertheless, indicated an increase in leg MCSA with PRT and the strength as $3.4 \%$.

All of the remaining eleven variables were measured in only one of the five studies with the sum of skinfolds (SSF), sum of limb girths (SLG) and thigh muscle volume the only variables showing significant change with PRT. Most of the variables (8) increased, with two decreasing and one did not change. No actual data was reported for thigh muscle volume 
Table 6. Percent change in body composition (from pre- to post-test) for the four progressive resistance training (PRT) studies.

\begin{tabular}{|c|c|c|c|c|c|c|c|c|c|c|c|c|c|c|c|c|c|}
\hline \multirow{2}{*}{\multicolumn{2}{|c|}{ Authors }} & \multicolumn{4}{|c|}{$\begin{array}{l}\text { Variable Measured in } \\
\text { Multiple Studies }\end{array}$} & \multicolumn{12}{|c|}{ Variable Measured in One Study Only } \\
\hline & & BM & FFM & FM & MCSA legs & SSF & SLC & TMV & BMI & $\begin{array}{l}\text { LBM } \\
\text { Arms }\end{array}$ & $\begin{array}{l}\text { LBM } \\
\text { Legs }\end{array}$ & $\begin{array}{c}\text { LBM } \\
\text { Trunk }\end{array}$ & $\begin{array}{l}\text { MCSA } \\
\text { (Quads) }\end{array}$ & $\begin{array}{l}\text { MCSA } \\
\text { (Hams) }\end{array}$ & TBW & TBW:FFM & BCM \\
\hline \multicolumn{2}{|l|}{ Spence et al. $(1990)^{+}$} & $5.1^{*}$ & & & & $15.7^{*}$ & $7.2^{*}$ & & & & & & & & & & \\
\hline \multicolumn{2}{|l|}{ Sattler et al. $(1999)^{+}$} & 1.3 & 2.6 & -5.4 & 0.3 & & & & & & & & 1.0 & -0.3 & & & 1.3 \\
\hline \multicolumn{2}{|l|}{ Shevitz et al. $(2005)^{+}$} & & 0.9 & & 3.1 & & & & 0.0 & & & & & & & & \\
\hline \multicolumn{2}{|c|}{ Bhasin et al. (2000): $\mathrm{DDM}^{+}$} & $4.3^{*}$ & 4.3 & 4.6 & & & & $\mathrm{NC}^{*}$ & & & & & & & 4.0 & -1.3 & \\
\hline \multicolumn{2}{|c|}{ Bhasin et al. (2000): DEXA ${ }^{+}$} & 18.8 & 15.8 & 28.3 & & & & & & 4.7 & 2.9 & 6.2 & & & & & \\
\hline \multicolumn{2}{|l|}{ Number of studies } & 4 & 4 & 3 & 2 & 1 & 1 & 1 & 1 & 1 & 1 & 1 & 1 & 1 & 1 & 1 & 1 \\
\hline \multicolumn{2}{|l|}{$\begin{array}{l}\text { Significant change } \\
\text { (No. of studies) }\end{array}$} & 2 & 0 & 0 & 0 & 1 & 1 & 1 & 0 & 0 & 0 & 0 & 0 & 0 & 0 & 0 & 0 \\
\hline \multirow{3}{*}{$\begin{array}{l}\text { Direction of change } \\
\text { per number of studies }\end{array}$} & $\uparrow$ & 4 & 4 & 2 & 2 & 1 & 1 & 1 & 0 & 1 & 1 & 1 & 1 & 0 & 1 & 0 & 1 \\
\hline & $\downarrow$ & 0 & 0 & 1 & 0 & 0 & 0 & 0 & 0 & 0 & 0 & 0 & 0 & 1 & 0 & 1 & 0 \\
\hline & $\leftrightarrow$ & 0 & 0 & 0 & 0 & 0 & 0 & 0 & 1 & 0 & 0 & 0 & 0 & 0 & 0 & 0 & 0 \\
\hline \multicolumn{2}{|l|}{ Strength of change (\%) } & 29.5 & 23.6 & 27.5 & 3.4 & 15.7 & 7.2 & $\mathrm{NC}$ & 0.0 & 4.7 & 2.9 & 6.2 & 1.0 & -0.3 & 4.0 & -1.3 & 1.3 \\
\hline
\end{tabular}

$\mathrm{BCM}$ = body cell mass; $\mathrm{BM}$ = body mass; $\mathrm{BMI}=$ body mass index; DDM = deuterium oxide dilution method; DEXA = dual energy X-ray absorptiometry; FFM = fat free mass; FM $=$ fat mass; hams $=$ hamstrings; LBM = lean body mass; MCSA = muscle cross- sectional area; quads $=$ quadriceps; SLG $=$ sum of limb girths $($ arm and thigh); SSF $=$ sum of skinfolds (chest, abdomen and thigh); TBW $=$ total body water; TMV $=$ thigh muscle volume; $\mathrm{NC}=$ not calculated.

$\uparrow=$ increased; $\downarrow=$ deceased; $\leftrightarrow=$ no change.

* Indicates significant change $(\mathrm{p}<0.05)$

${ }^{+}$Values expressed as percentages.

by Bhasin et al. [33], except for indicating the significant change in thigh muscle volume, which prevented any calculations being made from pre- to post-test.

Table 7 indicates the results of the three studies that used AT as the exercise intervention in persons with HIV. Although all three studies used standardised manual anthropometric techniques of assessment, the number and type of variables measured varied across the studies. Statistically significant differences in all, but one variable (hip circumference), were reported in the studies by Smith et al. [35] and Mutimura et al. [21]. The results in the study by Terry et al. [36] were all not significant.

The range of variables used to measure change in body composition, expressed as a percentage, across the different AT studies is presented in Table 8. The organization of the table is the same as previously explained for Table 6. All three studies measured BMI, with two showing a significant decrease, and one a non-significant increase. The overall strength of change for BMI was a decrease of $4.9 \%$. All three studies also measured WHR, with two showing a significant decrease and one a non-significant increase, with the overall strength as a decrease of $10.1 \%$. Triceps skinfolds were measured in two studies with both showing a significant decrease, with an overall strength of change as a decrease of $35.3 \%$. Waist circumference was measured in two studies with both showing significant decrease with the strength of change as a decrease of $11.0 \%$. Percent body fat was measured in two of the three studies with both showing a decrease, but only one was significant, with the overall strength of change as a decrease of $5.7 \%$. Body Mass was measured in two studies with one of the studies showing a significant decrease and the other no change, thus the overall strength of change was a decrease of $2.4 \%$. Hip circumference was measured in two studies with none of the studies showing significant change.

The studies were split with one indicating a decrease and the other an increase in hip circumference with AT with the strength of change being $0.2 \%$. All of the remaining nine variables were measured in only one of the three studies, with all (\%LBM, sum of central skinfolds, sum of peripheral skinfolds, sum of skinfolds, biceps skinfold, subscapular skinfold, suprailiac skinfold and body fat redistribution) showing a significant decrease, except for body density that showed no change.

Table 9 shows the results of the one study that used yoga as the exercise intervention in persons with HIV. A number of variables were measured using DEXA scanning. No statistically significant differences were reported in this study [34].

\section{Summary of Results}

To summarise the main outcomes of the two types of interventions (excluding yoga, as no significant differences were noted), PRT resulted in significant increases in four variables (body mass, sum of skinfolds and sum of limb girths, and thigh muscle volume) (Table 10). However, these changes were noted in separate studies only.

In contrast, AT resulted in significant decreases in several anthropometric variables (sum of skinfolds, BMI, WHR, waist circumference and triceps skinfolds) in multiple studies [21, 35]. Other significant changes were also noted in body mass, percent lean body mass, percent body fat, biceps, subscapular and suprailiac skinfolds, and overall sum of skinfolds (both peripheral and central), as well as body fat 
Table 7. Analysis of results from the three aerobic training (AT) studies.

\begin{tabular}{|c|c|c|c|c|c|c|c|c|c|c|c|c|}
\hline \multirow{2}{*}{ Authors } & \multirow{2}{*}{ Variables } & \multicolumn{4}{|c|}{ Control Group } & \multicolumn{4}{|c|}{ Experimental Group } & \multicolumn{2}{|c|}{ Between Groups } & \multirow{2}{*}{$p$-Value } \\
\hline & & Pre $^{+}$ & Post $^{+}$ & Diff. & $\%$ Change & Pre $^{+}$ & Post $^{+}$ & Diff. & $\%$ Change & Diff. & $\%$ Change & \\
\hline \multirow{8}{*}{ Smith et al. (2001) } & Body Mass (kg) & 84.6 & 85.1 & 0.5 & 0.6 & 83.9 & 82.4 & -1.5 & -1.8 & -2.0 & -2.4 & 0.04 \\
\hline & Body Mass Index $\left(\mathrm{kgm}^{-2}\right)$ & 27.5 & 27.7 & 0.2 & 0.7 & 26.5 & 26.0 & -0.5 & -1.9 & -0.7 & -2.6 & 0.035 \\
\hline & Triceps Skinfold (mm) & 16.4 & 17.6 & 1.2 & 7.3 & 11.3 & 9.1 & -2.2 & -19.5 & -3.4 & -26.8 & 0.014 \\
\hline & Sum of Skinfolds (central) (mm) & 74.9 & 74.9 & 0.0 & 0.0 & 55.4 & 49.2 & -6.2 & -11.2 & -6.2 & -11.2 & 0.02 \\
\hline & Sum of Skinfolds (peripheral) (mm) & 56.2 & 54.1 & -2.1 & -3.7 & 39.7 & 29.8 & -9.9 & -24.9 & -7.8 & -21.2 & 0.02 \\
\hline & Waist Circumference $(\mathrm{cm})$ & 94.2 & 94.5 & 0.3 & 0.3 & 92.3 & 89.7 & -2.6 & -2.8 & -2.9 & -3.1 & 0.02 \\
\hline & Hip Circumference (cm) & 98.3 & 97.3 & -1.0 & -1.0 & 95.2 & 93.5 & -1.7 & -1.8 & -0.7 & -0.8 & NS \\
\hline & Waist Hip Ratio & 0.96 & 0.97 & 0.0 & 1.0 & 0.97 & 0.96 & 0.0 & -1.0 & 0.0 & -2.1 & 0.003 \\
\hline \multirow{5}{*}{ Terry et al. (2006) } & Body Mass (kg) & 67.0 & 65.0 & -2.0 & -3.0 & 68.1 & 66.1 & -2.0 & -2.9 & 0.0 & 0.0 & NS \\
\hline & Body Mass Index $\left(\mathrm{kgm}^{-2}\right)$ & 24.0 & 23.0 & -1.0 & -4.2 & 25.0 & 24.0 & -1.0 & -4.0 & 0.0 & 0.2 & NS \\
\hline & Waist Hip Ratio & 0.94 & 0.91 & 0.0 & -3.2 & 0.91 & 0.90 & 0.0 & -1.1 & 0.0 & 2.1 & NS \\
\hline & Body density $\left(\mathrm{gcm}^{-3}\right)$ & 1.04 & 1.05 & 0.0 & 1.0 & 1.03 & 1.04 & 0.0 & 1.0 & 0.0 & 0.0 & NS \\
\hline & Body Fat $(\%)$ & 23.0 & 19.0 & -4.0 & -17.4 & 27.0 & 22.0 & -5.0 & -18.5 & -1.0 & -1.1 & NS \\
\hline \multirow{12}{*}{ Mutimura et al. (2008) } & Body Mass Index $\left(\mathrm{kgm}^{-2}\right)$ & 24.4 & 24.5 & 0.1 & 0.2 & 24.0 & 23.5 & -0.5 & -2.2 & -0.6 & -2.5 & $<.0001$ \\
\hline & Waist Circumference (cm) & 92.3 & 92.3 & 0.0 & 0.0 & 91.0 & 83.9 & -7.1 & -7.8 & -7.2 & -7.9 & $<.0001$ \\
\hline & Hip Circumference (cm) & 93.7 & 93.9 & 0.2 & 0.2 & 92.3 & 93.4 & 1.1 & 1.2 & 0.9 & 1.0 & NS \\
\hline & Waist Hip Ratio & 0.98 & 0.98 & 0.0 & 0.0 & 0.99 & 0.89 & -0.1 & -10.1 & -0.1 & -10.1 & $<.0001$ \\
\hline & Body Fat Redistribution score (7-item) & 18.7 & 19.2 & 0.5 & 2.7 & 19.3 & 14.6 & -4.7 & -24.4 & -5.2 & -27.1 & $<.0001$ \\
\hline & Triceps Skinfold (mm) & 14.4 & 14.2 & -0.2 & -1.4 & 14.4 & 13.0 & -1.4 & -9.9 & -1.2 & -8.5 & $<.0001$ \\
\hline & Biceps Skinfold (mm) & 10.8 & 10.7 & -0.1 & -0.6 & 10.7 & 10.1 & -0.6 & -5.9 & -0.6 & -5.3 & $<.05$ \\
\hline & Subscapular Skinfold (mm) & 18.7 & 18.2 & -0.6 & -2.9 & 18.6 & 16.7 & -1.9 & -10.2 & -1.4 & -7.3 & $<.0001$ \\
\hline & Suprailiac Skinfold (mm) & 18.8 & 18.4 & -0.4 & -2.3 & 18.7 & 16.6 & -2.1 & -11.2 & -1.7 & -8.9 & $<.0001$ \\
\hline & Sum of Skinfolds (mm) & 62.7 & 61.5 & -1.3 & -2.0 & 62.3 & 56.2 & -6.2 & -9.9 & -4.9 & -7.9 & $<.0001$ \\
\hline & Lean Body Mass (\%) & NR & NR & $\mathrm{NC}$ & $\mathrm{NC}$ & NR & NR & $\mathrm{NC}$ & $\mathrm{NC}$ & $\mathrm{NC}$ & $\mathrm{NC}$ & $<.0001$ \\
\hline & Body Fat (\%) & 29.3 & 29.1 & -0.2 & -0.5 & 29.4 & 27.9 & -1.5 & -5.1 & -1.3 & -4.6 & $<.0001$ \\
\hline
\end{tabular}

Diff. $=$ difference; $\mathrm{NC}=$ not calculated; $\mathrm{NR}=$ not reported; $\mathrm{NS}=$ not significant.

Central skinfolds $=$ subscapular, suprailiac and abdominal; Peripheral skinfolds $=$ triceps, biceps, thigh and medial calf; Sum of skinfolds $=$ biceps, triceps, subscapular and suprailiac.

${ }^{+}$Values indicated as means.

redistribution) (Table 10). However, all these changes were found in separate studies and not repeated. There were no significant changes noted as a result of yoga training.

\section{DISCUSSION}

This review was based on randomised controlled studies that investigated the influences of different types of training interventions applied at various intensities and sustained over short- and long- term periods on the anthropometric and body composition measurements of adults living with HIV. Numerous studies have focused on this topic but, because of methodological shortcomings such as a lack of randomisation or control, were excluded from this review.

The body composition of individuals living with HIV is not similarly affected by different types of training interventions [21, 23, 24, 28, 35, 37-42]. For instance, in the studies that focussed on PRT, there was some evidence of tissue anabolism with significant increases in body mass and muscle size $[31,33]$. The increase in muscle size also resulted in improved muscle strength [33]. Also, the increase in muscle size (hypertrophy) was primarily as a result of lean mass (protein) accretion [33]. It was difficult to establish the range of increase in FFM with PRT, because of the limited number of studies, as well as determining the range of increase in FFM that was clinically significant. Similar difficulties were observed in other reviews [24, 27, 28]. Also, whether the effect of resistance training combined with testosterone therapy is additive (dose-response effect) has not been demonstrated by this review, and warrants further study. However, PRT may provide the exercise stimulus to augment the effects of anabolic treatment and thereby enhance muscle mass, in both quantity (increased size) and quality (improved strength) $[19,38]$. Therefore, early intervention with resistance training may slow the 
Table 8. Percent change in body composition (from pre- to post-test) for the three aerobic training (AT) studies.

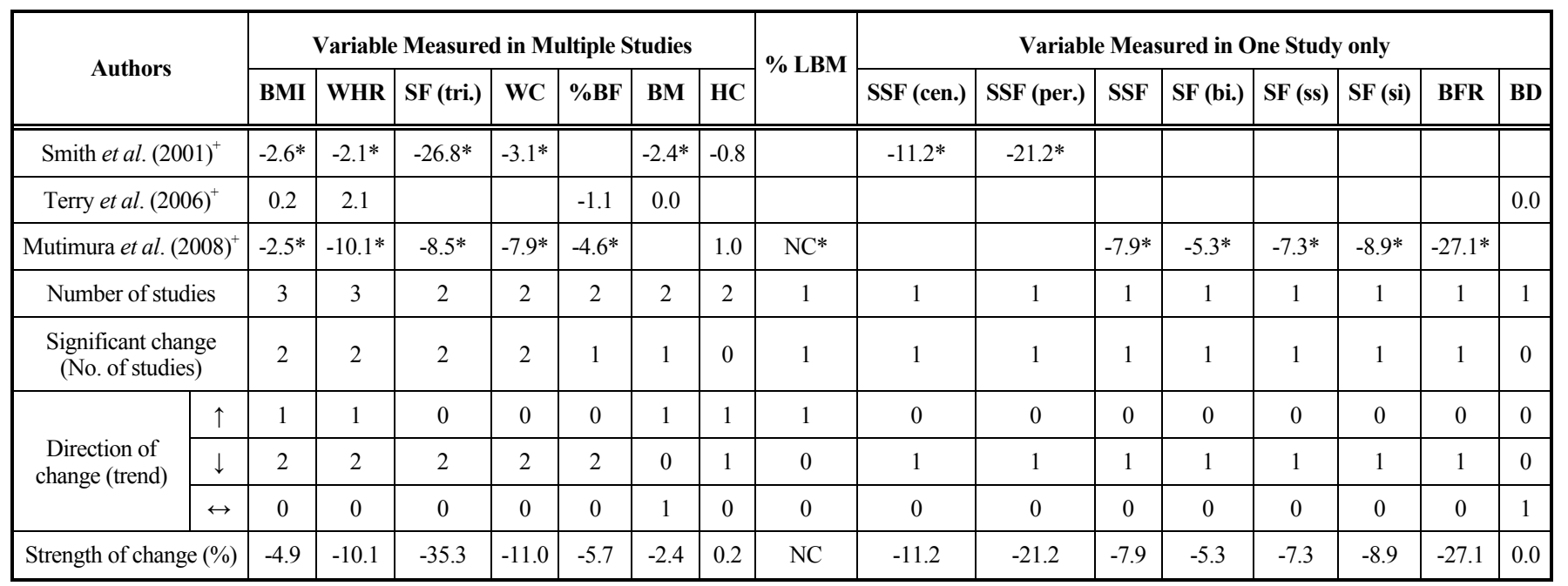

$\% \mathrm{BF}=$ percent body fat; $\mathrm{BD}=$ body density; $\mathrm{BFR}=$ body fat redistribution; $\mathrm{BM}=$ body mass; $\mathrm{BMI}=$ body mass index; HC = hip circumference; \%LBM = percent lean body mass;

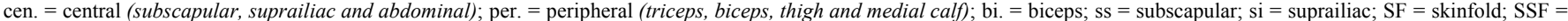
sum of skinfolds (triceps, biceps, subscapular and suprailiac); WC = waist circumference; WHR = waist hip ratio.

$\uparrow=$ increased; $\downarrow=$ deceased; $\leftrightarrow=$ no change.

* Indicates significant change $(\mathrm{p}<0.05)$.

${ }^{+}$Values expressed as percentages.

progression of muscle atrophy and delay the debilitating effects that are commonly associated with HIV infection.

Important to note, is that PRT should be based on recruiting major muscle groups, such as the arms, chest, back, abdomen and legs. Frequency of exercise should be 23 sessions/week. The exercise intensity should range between $60-80 \% 1 \mathrm{RM}$, with enough time to perform 1-3 sets of 8-12 reps of exercise for each major muscle group. Equally noteworthy, the exercise programmes should be individualized according to the participants' symptoms and exercise capacity to ensure safety and efficacy. For individuals in the advanced stages of infection, training must be carefully managed and, if indicated, must be supervised to avoid precipitating any adverse events. The adherence rate is also a critical factor in determining exercise efficacy and tissue response effects.

The recommended dosage of AT shown to be effective in this review was based on the FITT principle, i.e., exercise frequency: 3-5 sessions/week; exercise intensity: 50-85\% age-predicted maximal heart rate (APMHR), 45-85\% $\mathrm{VO}_{2 \max }$ or the Borg rating of perceived exertion (RPE) scale of 1114; exercise time: 30-60 minutes; and exercise type: prolonged endurance exercise involving large muscle groups, such as those used in walking, running, swimming, etc.

Subject adherence in the various studies was fairly high at $87.4 \%$, and did not vary by much based upon the various types of exercise interventions, i.e., whether PRT, AT or yoga. However, subject compliance with the exercise intervention specifically was less satisfactory, and may have affected the magnitude of the change in the body composition and the level of statistical significance.

In the African context, limited resources and therapies exist for HIV and/or AIDS wasting syndrome [43, 44]. Therefore, the use of easily accessible and simple resources and measurements in the modification of risk has become an increasingly important aspect of HIV management. Patients with AIDS-related wasting have substantial muscle loss and muscle dysfunction that is often complicated by truncal obesity and lipodystrophy syndrome [44, 45]. In HIVinfected men and women with fat redistribution due to HAART use, supervised exercise training has the potential to significantly reduce central fat adiposity secondary to increasing muscle mass and, thereby, provide a cardioprotective effect $[22,45]$. The results of this review are therefore particularly relevant for the large population of $\mathrm{HIV}$-infected persons living on the African continent, more especially in sub-Saharan Africa, where adopting relatively simple but fundamental lifestyle changes, such as exercising regularly, eating healthy and reducing stress, can make meaningful improvements to health and quality of life. Furthermore, where access to HAART medication is limited, these lifestyle changes can provide a cost-effective healthy alternative in this vulnerable population.

The shortcomings of the studies selected in this review relate to the variable statistical quality applied, with a number of the studies not reporting adequately on the statistics used. Also, the differences in study methodology and variables measured precluded adequate comparisons. For instance, where studies reported on BMI, no data was provided for stature in some studies, and sometimes not even for body mass, which created incomplete results. Researchers also need to be mindful of the variables measured and the precision of measurement, by using of modern body composition assessment equipment (DEXA, MRI and CT scans), so that appropriate comparisons can be made. Finally, one of the main shortcomings was the limited number of subjects recruited within these studies, possibly resulting in the lack of statistical significance reported in most of the studies. Possible reasons for this could relate to the low statistical power stemming from attrition bias, unequal treatment and control groups, and confounding variables, e.g., there were no long-term studies $(>24$ months). 
Table 9. Analysis of results from the yoga study.

\begin{tabular}{|c|c|c|c|c|c|c|c|c|c|c|c|c|}
\hline \multirow{2}{*}{ Authors } & \multirow{2}{*}{ Variables } & \multicolumn{4}{|c|}{ Control Group } & \multicolumn{4}{|c|}{ Experimental Group } & \multicolumn{2}{|c|}{ Between Groups } & \multirow{2}{*}{$p$-Value } \\
\hline & & Pre $^{+}$ & Post $^{+}$ & Diff. & $\%$ Change & Pre $^{+}$ & Post $^{+}$ & Diff. & $\%$ Change & Diff. & $\%$ Change & \\
\hline \multirow{6}{*}{ Cade et al. (2010) } & Body Mass (kg) & 78.4 & 78.0 & -0.4 & -0.5 & 80.9 & 80.4 & -0.5 & -0.6 & -0.1 & -0.1 & NS \\
\hline & Body Fat (\%) & 19.9 & 19.5 & -0.4 & -2.0 & 19.6 & 19.4 & -0.2 & -1.0 & 0.2 & 1.0 & NS \\
\hline & Limb Fat Mass (kg) & 8.4 & 8.3 & -0.1 & -1.2 & 7.5 & 7.4 & -0.1 & -1.3 & 0.0 & -0.1 & NS \\
\hline & Trunk Fat Mass (kg) & 11.5 & 11.2 & -0.3 & -2.6 & 12.1 & 12.0 & -0.1 & -0.8 & 0.2 & 1.8 & NS \\
\hline & Lean Body Mass (kg) & 57.5 & 57.5 & 0.0 & 0.0 & 60.3 & 57.7 & -2.6 & -4.3 & -2.6 & -4.3 & NS \\
\hline & Limb Lean Mass (kg) & 24.9 & 24.8 & -0.1 & -0.4 & 25.9 & 26.4 & 0.5 & 1.9 & 0.6 & 2.3 & NS \\
\hline
\end{tabular}

${ }^{+}$Values indicated as means.

Table 10. Summary table of the body composition changes with various training interventions.

\begin{tabular}{|c|c|c|c|c|c|c|c|c|c|c|c|c|c|c|c|c|c|c|}
\hline $\begin{array}{l}\text { Study } \\
\text { Type }\end{array}$ & Authors & BM & SSF & SLG & TMV & BMI & WHR & WC & SF (tri.) & SF (bi.) & SF (ss) & SF (si) & SSF (cen.) & SSF (per.) & SSF & $\%$ LBM & $\% \mathrm{BF}$ & BFR \\
\hline PRT & $\begin{array}{l}\text { Spence } \text { et al. } \\
\quad(1990)\end{array}$ & 5.1 & 15.7 & 7.2 & & & & & & & & & & & & & & \\
\hline PRT & $\begin{array}{l}\text { Bhasin et al. } \\
(2000)\end{array}$ & 4.3 & & & $\mathrm{NC}$ & & & & & & & & & & & & & \\
\hline AT & $\begin{array}{l}\text { Smith et al. } \\
\quad(2001)\end{array}$ & -2.4 & & & & -2.6 & -2.1 & -3.1 & -26.8 & & & & -11.2 & -21.2 & & & & \\
\hline AT & $\begin{array}{l}\text { Mutimura et al. } \\
\text { (2008) }\end{array}$ & & & & & -2.5 & -10.1 & -7.9 & -8.5 & -5.3 & -7.3 & -8.9 & & & -7.9 & $\mathrm{NC}$ & -4.6 & -27.1 \\
\hline
\end{tabular}

AT = aerobic raining; BMI = body mass index; BM = body mass; cen. = central; per. = peripheral; PRT = progressive resistance training; $\mathrm{SF}=$ skinfold; SLG = sum of limb girths; $\mathrm{SSF}=$ sum of skinfolds; $\mathrm{WC}=$ waist circumference; $\mathrm{WHR}=$ Waist-hip ratio $\mathrm{NC}=$ not calculated.

Values expressed as percentages.

\section{Key Messages of this Review}

In PRT studies:

- There were significant changes in some anthropometric characteristics that were shown individual studies only.

- There is some evidence supporting directional changes in certain measures of body composition such as FFM and MCSA legs.

- The benefits accruing from progressive resistance training favour weight gain, particularly lean tissue anabolism)

In AT studies:

- There were significant changes in some anthropometric characteristics that were shown in multiple studies

- The benefits accruing from aerobic, endurance training favour fat loss, fat redistribution and cardiovascular risk reduction, particularly adipose tissue catabolism.

The changes in body composition resulting from PRT and AT are training-specific, based upon the FITT training principle, i.e., exercise frequency, intensity, time and type.

\section{Unique Contributions of this Review}

This review shows that PRT produces primarily an anabolic effect, whereas AT appears to produce an antagonistic effect that causes significant tissue catabolism, particularly in fat mass, combined with improvements body fat redistribution and fat loss. The strength of this review is the application of a quality scoring system involving several independent reviewers and that the authors undertook an exhaustive search of the literature using well-established databases, inclusive of manual tracking and collaboration with experts in the field. Also, the key information is that simple lifestyle changes that include exercise can further benefit the patient in addition to using ART.

\section{Limitations of this Review}

The limitations of this systematic review relate primarily to the limited number of studies identified, despite the extensive search through numerous electronic databases. This review reiterates the widespread paucity of quality evidence based on randomized controlled trials about the efficacy of exercise interventions for persons with HIV. It is evident from the results of the eight (8) studies selected caution should be observed regarding the generalizability of the findings. Furthermore, this review did not extend to 
consider studies that investigated the impact of concurrent strength and aerobic training, in combination, on the body composition of individuals living with HIV/AIDS.

\section{CONCLUSION}

This review shows that progressive resistance training, when performed at least twice weekly, and AT, when performed at least thrice weekly, for a minimum of 6 weeks appears to be well-tolerated, and produce significant improvements in selected anthropometric and body composition characteristics. However, the changes produced by each type of intervention are programme-specific and distinct, and do not appear to be time-dependent. This review also demonstrates favourable trends towards risk reduction, i.e., the improvement body fat redistribution and in body composition, primarily derived from AT. Such changes are positive and encouraging in helping to attenuate the ARTrelated lipodystrophy. In the absence of a cure for HIV/AIDS, including PRT and AT interventions in the overall care and effective management of adults with HIV are clinically important and relatively safe nonpharmacological treatments, particularly in developing countries such as sub-Saharan Africa where access to HAART is often highly regulated and less than optimal. If well-planned and individualised, exercise appears to be therapeutic and beneficial in maintaining functional capacity and enhancing quality of life for persons with HIV.

\section{AUTHORS' CONTRIBUTIONS}

L.L. Leach, S.H. Bassett, G. Smithdorf, B.S. Andrews and A.L. Travill collected the data. SHB prepared the data set for analyses, and L.L. Leach conducted the data analyses. S.H. Bassett and L.L. Leach contributed to the interpretation of the results and A.L. Travill to the drafting the discussion. All authors initiated this collaboration and helped to draft and revise the manuscript. All authors read and approved the manuscript for submission.

\section{AUTHORS' INFORMATION}

L.L. Leach, S.H. Bassett and G. Smithdorf are specialists in biokinetics (exercise therapy), B.S. Andrews is a specialist motor learning and sport technology, and A.L. Travill is a Professor specializing in anthropometry.

\section{LIST OF ABBREVIATIONS}

$$
\begin{array}{ll}
1 \mathrm{RM} & =\text { One repetition maximum. } \\
\mathrm{AIDS} & =\text { Acquired immune deficiency syndrome } \\
\mathrm{AT} & =\text { Aerobic training } \\
\mathrm{CT} & =\text { Computerised tomography } \\
\mathrm{DDM} & =\text { Deuterium dilution method } \\
\text { DEXA } & =\text { Dual energy X-ray absorptiometry } \\
\text { HAART } & =\text { Highly active antiretroviral therapy } \\
\text { HIV } & \text { Human immunodeficiency virus } \\
\text { MCSA } & \text { Muscle cross-sectional area }
\end{array}
$$

$$
\begin{array}{ll}
\text { MRI } & =\text { Magnetic resonance imaging } \\
\text { PRT } & =\text { Progressive resistance training } \\
\text { RCTs } & =\text { Randomised controlled trials }
\end{array}
$$

\section{CONFLICT OF INTEREST}

The authors declare that there have been no conflict of interest in the compilation of this review.

\section{ACKNOWLEDGEMENTS}

The authors thank Professors Nicolette Roman and José Frantz for helping with the methodology of the systematic review, identifying relevant quality appraisal assessment tools and guiding the reviewers through the systematic review process.

\section{REFERENCES}

[1] Antiretroviral Therapy Cohort Collaboration. Life expectancy of individuals on combination antiretroviral therapy in high-income countries: a collaborative analysis of 14 cohort studies. Lancet 2008; 372: 293-9.

[2] Palella Jr FJ, Delaney KM, Moorman AC, et al. Declining morbidity and mortality among patients with advanced human immunodeficiency virus infection. HIV Outpatient Study Investigators. N Engl J Med 1998; 338: 853-60.

[3] Carr A, Samaras K, Thorisdottir A, et al. Diagnosis, prediction, and natural course of HIV1-protease inhibitor-related lipodystrophy, hyperlipidaemia, and diabetes mellitus: a cohort study. Lancet 1999; 353: 2093-9.

[4] Carr A, Samaras K, Burton S, et al. A syndrome of peripheral lipodystrophy, hyperlipidaemia and insulin resistance in patients receiving HIV protease inhibitors. AIDS 1998; 12: F51-8.

[5] Safrin S, Grunfeld C. Fat distribution and metabolic changes in patients with HIV infection. AIDS 1999; 13: 1373-5.

[6] Carr A, Emery S, Law M, et al. An objective case definition of lipodystrophy in HIV-infected adults. Lancet. 2003; 361: 726-35.

[7] Kotler DP, Thea Dm, Heo M, et al. Relative influences of sex, race, environment, and HIV infection on body composition in adults. Am J Clin Nutr 1999; 69: 432-9.

[8] Larsson L, Svardsudd K, Welin L, et al. Abdominal adipose tissue distribution, obesity, and risk of cardiovascular disease and death: 13 year follow up of participants in the study of men born in 1913 . BMJ 1984; 288: 1401-4.

[9] Manson JE, Golditz GA, Stampfer MJ, et al. A prospective study of obesity and risk of coronary heart disease in women. N Engl J Med 1990; 322: 882-9.

[10] Grinspoon S, Carr A. Cardiovascular risk and body-fat abnormalities in HIV-infected adults. N Engl J Med 2005; 352: 4862.

[11] Friis-Moller N, Satin CA, Weber R, et al. Combination antiretroviral therapy and risk of myocardial infarction. N Engl J Med 2003; 349: 1993-2003.

[12] Flynn TE, Bricker LA. Myocardial infarction in HIV-infected men receiving protease inhibitors. Ann Intern Med 1999; 131: 548.

[13] Folsom AR, Kaye SA, Sellers TA, et al. Body fat distribution and 5-year risk of death in older women. JAMA 1993; 269: 483-7.

[14] American College of Sports Medicine. ACSM's Guidelines for Exercise Testing and Prescription. $8^{\text {th }}$ ed. Lippincott, Williams \& Wilkins, Philadelphia: USA 2010; p. 64.

[15] Galli M, Ridolfo AL, Adorni f, et al. Body habitus changes in metabolic alterations in protease inhibitor-naïve HIV-1 infected patients treated with two nucleoside reverse transcriptase inhibitors. J Acquir Immune Defic Syndr 2002; 29(1): 21-31.

[16] Lo JC, Mulligan K, Tai VW, et al. "Buffalo hump" in men with HIV-1 infection. Lancet 1998; 351: 867-70.

[17] Bopp CM, Phillips KD, Fulk LJ, et al. Physical activity and immunity in HIV-infected individuals. AIDS Care 2004; 16(3): $387-93$. 
[18] Clingerman, EM. Participation in physical activity by persons living with HIV disease. J Assoc Nurses AIDS Care 2003; 14(5): 59-70.

[19] Sattler FR, Jaque SV, Schroeder ET, et al. Effects of pharmacological doses of nandrolone decanoate and progressive resistance training in immunodeficient patients infected with human immunodeficiency virus. J Clin Endocrinol Metab 1999; 84: 1268-76.

[20] Yahiaoui A, McGough EL, Voss JG. Development of evidencebased exercise recommendations for older HIV-infected patients. J Assoc Nurses AIDS Care 2012; 23(3): 204-19.

[21] Mutimura E, Crowther NJ, Cade TW, Yarasheski KE, Stewart A. Exercise training reduces central adiposity and improves metabolic indices in HAART-treated HIV-positive subjects in Rwanda: a randomized controlled trial. AIDS Res Hum Retrov 2008; 24(1): $15-23$.

[22] Roubenoff R, Weiss L, McDermott A, et al. A pilot study of exercise training to reduce trunk fat in adults with HIV-associated fat redistribution. AIDS 1999; 13: 1373-5.

[23] Guaraldi G, Orlando G, Squillace N, et al. Multidisciplinary approach to the treatment of metabolic and morphologic alterations of HIV-related lipodystrophy. HIV Clin Trials 2006; 7(3): 97-106.

[24] O'Brien K, Tynan AM, Nixon S, Glazier RH. Effects of progressive resistive exercise in adults living with HIV/AIDS: systematic review and meta-analysis of randomized trials. AIDS Care 2008; 20(6): 631-53.

[25] O'Brien K, Nixon S, Tynan AM, Glazier R. Aerobic exercise interventions for adults living with HIV/AIDS. Cochr Database Syst Rev 2010; 8: CD001796.

[26] Neto GM, Ogalha C, Andrade AM, Brites C. A systematic review of concurrent strength and endurance training on the health-related quality of life and cardiopulmonary status in patients with HIV/AIDS. BioMed Res Int 2013; 2013: 319524.

[27] Malita FM, Karelis AD, Toma E, Rabasa-Lhoret R. Effects of different types of exercise on body composition and fat distribution in HIV-infected patients: a brief review. Can J Appl Physiol 2005; 30(2): $233-45$

[28] Filipas S, Cherry CL, Cicuttini FM, et al. The effects of exercise training on metabolic and morphological outcomes for people living with HIV: a systematic review of randomised controlled trials. HIV Clin Trials 2010; 11(5): 270-82.

[29] Roman NV, Frantz JM. The prevalence of intimate partner violence in the family: a systematic review of the implications for adolescents in Africa. Fam Prac 2013; 30(3): 256-65.

[30] Wong WC, Cheung CS, Hart GJ. Development of a quality assessment tool for systematic reviews of observational studies (QATSO) of HIV prevalence in men having sex with men and associated risk behaviours. Emerg Themes Epidemiol 2008; 5: 23.
[31] Spence DW, Galantino MLA, Kurt MS, et al. Progressive resistance exercise: effect of muscle function and anthropometry of a select AIDS population. Arch Phys Med Rehab 1990; 71: 644-8.

[32] Shevitz AH, Wilson IB, McDermott AY, et al. A comparison of the clinical and cost-effectiveness of 3 intervention strategies for AIDS wasting. J Acquir Immune Defic Syndr 2005; 38(4): 399-406.

[33] Bhasin S, Storer TW, Javanbakht $\mathrm{M}$, et al. Testosterone replacement and resistance exercise in HIV-infected men with weight loss and low testosterone levels. J Am Med Assoc 2000; 283: 763-70.

[34] Cade WT, Reeds, DN, Mondy KE, et al. Yoga lifestyle intervention reduces blood pressure in HIV-infected adults with cardiovascular disease risk factors. HIV Med 2010; 11(6): 379-88.

[35] Smith BA, Neidig JL, Nickel JT, et al. Aerobic exercise: effects on parameters related to fatigue, dyspnea, weight and body composition in HIV-infected adults. Acquir Immune Defic Syndr 2001; 15: 693-701

[36] Terry L, Sprinz E, Stein R, et al. Exercise training in HIV-1infected individuals with dyslipidemia and lipodystrophy. Med Sci Sports Exerc 2006; 38(3): 411-7.

[37] De Souza PML, Filho, WJ, Santarém JM, et al. Progressive resistance training in elderly HIV-positive patients: does it work? Clinics 2008; 63(5): 619-24.

[38] Dolan SE, Frontera W, Librizzi J, et al. Effects of a supervised home-based aerobic and progressive resistance training regimen in women infected with human immunodeficiency virus: a randomized trial. Arch Intern Med 2006; 166(11): 1225-31.

[39] Engelson ES, Agin D, Kenya S, Body composition and metabolic effects of a diet and exercise weight loss regimen on obese, HIVinfected women. Metabolism 2006; 55: 1327-36.

[40] Lindegaard B, Hansen T, Hvid T. The effect of strength and endurance training on insulin sensitivity and fat distribution in human immunodeficiency virus-infected patients with lipodystrophy. J Clin Endocrinol Metab 2008; 93(10): 3860-9.

[41] Lox CL, McAuley E, Tucker RS. Aerobic and resistance exercise training effects on body composition, muscular strength, and cardiovascular fitness in an HIV-1 population. Int J Behav Med 1996; 3(1): 55-9.

[42] Filipas S, Cicuttini FM, Holland AE, Cherry CL. Physical activity participation and cardiovascular fitness in people living with HIV. A one-year longitudinal study. J AIDS Clin Res 2013; S9: 002.

[43] Harries AD. Management of HIV in resource-poor countries, with a focus on sub-Saharan Africa. Lepr Rev 2002; 73(3): 268-75.

[44] Badri M, Lawn SD, Wood R. Short-term risk of AIDS or death in people infected with HIV-1 before antiretroviral therapy in South Africa: a longitudinal study. Lancet 2006; 368(9543): 1254-9.

[45] Grinspoon S, Corcoran C, Parlman K, et al. Effects of testosterone and progressive resistance training in eugonadal men with AIDS wasting. Ann Intern Med 2000; 133: 348-55.

Received: July 31, 2015

Revised: August 8, 2015

Accepted: August 16, 2015

(C) Leach et al.; Licensee Bentham Open.

This is an open access article licensed under the terms of the Creative Commons Attribution Non-Commercial License (http://creativecommons.org/licenses/by-nc/ 3.0/) which permits unrestricted, non-commercial use, distribution and reproduction in any medium, provided the work is properly cited. 